Filene, B. Sense of History: The Place of the Past in American Life, by David Glassberg, Minnesota History 57.7 (fall $2001): 382-383$

Copyright of Minnesota History is the property of the Minnesota Historical Society and its content may not be copied or emailed to multiple sites or posted to a listserv without the copyright holder's express written permission. Users may print, download, or email articles, however, for individual use.

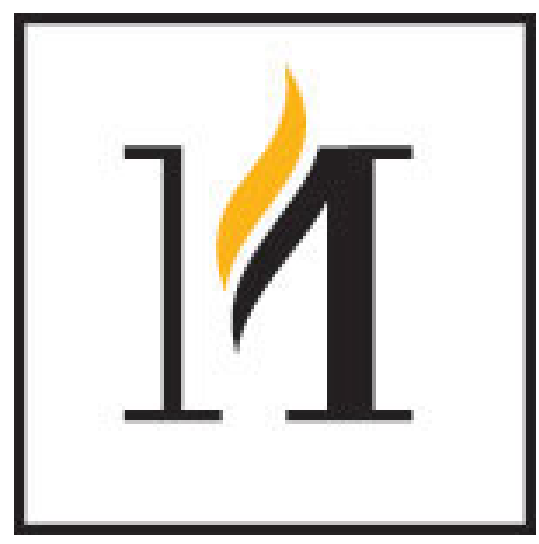

\title{
Minnesota Historical Society
}

Sense of History: The Place of the past in American Life by David Glassberg Review by: Benjamin Filene Minnesota History, Vol. 57, No. 7 (Fall, 2001), pp. 382-383

Published by: Minnesota Historical Society Press

Stable URL: http://www.jstor.org/stable/20188278

Accessed: 07/03/2013 10:05

Your use of the JSTOR archive indicates your acceptance of the Terms \& Conditions of Use, available at http://www.jstor.org/page/info/about/policies/terms.jsp

JSTOR is a not-for-profit service that helps scholars, researchers, and students discover, use, and build upon a wide range of content in a trusted digital archive. We use information technology and tools to increase productivity and facilitate new forms of scholarship. For more information about JSTOR, please contact support@jstor.org. 
For all of its merits, the book has several limitations as a work of history. Senior administrators and selected faculty members figure prominently as they and their academic units march across the pages like entries in a college yearbook with little cohesion or context. Although this can be partly attributed to the size and complexity of the university, the authors relegate overviews and major themes briefly to the book's acknowledgements and epilogue with no development in the main narrative. The University of Minnesota's emergence as a large, multicampus system conformed to a national trend after World War II, yet the only reference to this appears in a footnote. Major events such as acquisition of the Duluth campus in 1947 , building the West Bank campus in Minneapolis during the early 1960 , and closing the Waseca campus in 1992 just seem to happen with little examination of circumstances. The book, sponsored by the University of Minnesota, also has the quality of a court history that can benefit from familiarity but can lack detachment. The authors themselves have had long-term affiliations with the university's Twin Cities campus, Lehmberg as a renowned scholar and chair of the history department, Pflaum as a graduate student and later an administrator.

As a sequel to James Gray's University of Minnesota $I 85^{I-195 I}\left(195^{1}\right)$, this book brings the story of the university to the end of the twentieth century. It is a valuable reference work and a necessary point of departure for scholars conducting further research on the university. It also serves as a source for past and present members of the university's community to reminisce about a favorite faculty member, a colleague, a memorable experience, and other ways that the University of Minnesota touched their lives.

Reviewed by Mitchell Rubinstein, who received the Ph.D. in history from the University of Minnesota, lives in St. Paul, and works in higher education.

\section{Sense of History: The Place of the Past in American Life}

\section{By David Glassberg}

(Amherst: University of Massachusetts Press, 2001. 269 p. Cloth, \$50.oo; paper, \$18.95.)

David Glassberg's BooK is a searching exploration of the divide that separates academic history from the sense of the past that all of us carry wherever we go-our sense of having ancestors, of being from someplace, of being connected to traditions. "Must there be such a gulf between scholarly and personal uses of the past?" he asks.

Glassberg pursues this theme across five distinct yet interconnected essays, each of which analyzes ordinary Americans actively defining and deploying history: a
Massachusetts town debating what sort of statue should commemorate its World War I veterans, the city leaders of San Francisco mounting an historical festival in 1909, viewers of Ken Burns's Civil War television series writing him heartfelt letters, contemporary residents of three Massachusetts towns struggling to define their town character, and Californians setting out to mark the historic features of their landscape. Two overview chapters about Americans' sense of history and of place put these essays into context.

Throughout the volume, Glassberg argues that popular representations of history, although perhaps loose with facts and thin on theory, carry an emotional clout lacking in academic work. Whether raising an historical marker or staging a commemorative parade, ordinary Americansout of instinct and self-interest-tell stories about the past that are rooted in personal emotion and a firm sense of place. Academics, driven by their own professional imperatives and self-interests, de-emphasize these same qualities, producing analyses bereft of personal voice and divorced from local geography. The time has come, Glassberg feels, for academic historians to reveal themselves: "Our own experiences, our own families, our own communities, can be the source of historical insights. ... [W] e can establish who we are only by writing from a place, from a community, from a location in the world."

True to this theme, Glassberg is at his best when closest to the ground. His chapter on "Remembering a War" offers an astonishingly rich, step-by-step account of the process that Orange, Massachusetts, went through in memorializing its World War I dead. Shortly after the surviving veterans returned to town in 1919 , there was talk of building a memorial arch or obelisk. After heated debate, the town voted instead to build a "living memorial," a downtown park, without commemorative statuary. For the next decade and a half, veterans groups pressed for a threedimensional tribute within the park. Glassberg traces their efforts to sway public opinion, the various designs considered along the way, and then, most strikingly, the transformation in the 193 os of the commemoration effort into an anti-war campaign. Spurred by revelations of profiteering during World War I and by the despair of the Great Depression, a pacifism movement was sweeping across America. In Orange, the movement penetrated some surprising enclaves. For Memorial Day, 1931, the high-school principal wrote an article for the school paper, urging students who watched the veterans on parade to imagine "shell-torn mud-spattered, bleeding humanity as it was on the fields of France. While the band is playing a stirring march, I hope that you will hear the cry of suffering humanity as God has heard it through all the wars of the ages." The town's young clergyman, Wallace Fiske, addressed veterans in a similar vein in a $193^{2}$ sermon. When the veterans finally won their memorial statue in the park in 1934, it did not depict a heroic fighter. It shows a weary veteran painfully recounting his war experiences to an angry and disillusioned young boy. 
Recounting these twists and turns, Glassberg demonstrates the power of "microhistory" at its best. He animates the story of the pacifism movement with truth-fixing details: the Massachusetts branch of the Women's International League for Peace and Freedom distributing "peace kits"; Orange high-school students eager to enlist in the Second World War being required first to look through a book showing explicit photos of World War I casualties; residents ignoring the monument during World War II and then, briefly, rediscovering it as an oppositional site during Vietnam War protests; Wallace Fiske rededicating the refurbished memorial in 1998 , 66 years after his impassioned anti-war sermon. Glassberg's sensitive account reveals the past as an ever-shifting mosaic of interpretations and re-interpretations, each of which draws life from-and sustains-the people who embrace them.

Compared to this intimacy, his analysis in other chapters seems detached. The essay on marking historical sites in California is rich in detail, but his chapter on Ken Burns is surprisingly lifeless. He codes a random sample of 444 letters sent to Burns according to the subjects they address-for example: " 10 percent . . . commented on his use of still photographs, 14 percent on his use of music, 21 percent praised the way he incorporated diaries and letters into his film." Is science of this sort really the best way to understand what Burns's letter-writers can tell us? Glassberg's exploration of town character in New England likewise relies on sketchy social science. He conducted a series of public meetings in three Massachusetts towns, attended by a self-selected group of residents. He con- cludes that different people within these groups bring their own perspectives to the towns, not always subscribing to the "official" Chamber-of-Commerce definition of town character. Is this news? Perhaps a less artificially assembled body would have led Glassberg to richer findings. Finally, the book's overview chapters ("Sense of History" and "Place and Placelessness in American History") display a truly impressive command of recent scholarship but have a dutiful air, lacking the passion that animates his more detailed accounts.

Part of the issue, perhaps, is that for all his idealism about the power of history in ordinary people's lives, Glassberg defines his audience as academics. At several points, he directly addresses his "fellow historians," and he concludes by reflecting on what he wants to convey to his graduate students about the practice of history. Although a path-breaker in pursuing public history, Glassberg seems to be reaching back to address academics on their own terms, sometimes at the expense of the richly human stories he prizes.

Perhaps such trade-offs are the essence of a bridgebuilding work such as this one: residents on both banks want to see the go-between as their own. If at times Sense of History seems a bit dry, it nonetheless offers exemplary models of a personally revealing, honest, and geographically rooted exploration of how Americans make the past their own.

Reviewed by Benjamin Filene, an exhibit curator at the Minnesota Historical Society and the author of Romancing the Folk: Public Memory and American Roots Music (200o).

\section{N E W S $\&$ \& O T E S}

RICH WITH DETAIL and captivating in its variety, Diaries of Girls and Women: A Midwestern American Sampler edited by Suzanne L. Bunkers (Madison: University of Wisconsin Press, 2001, 457 p., paper, \$24.95) presents excerpts from the diaries of 46 girls and women who lived in Minnesota, Iowa, or Wisconsin between 1837 and 1999. The book's chapters-American Girls, Coming of Age, Journeys, and Home, Work, and Family-highlight both the diversity of experience and the common threads that run through the diarists' lives. Entries are chronological within each section. Bunkers's introduction explores the theory and practice of writing and reading diaries, and her introductory notes on each diarist further enhance the volume.

FIRST PUBLISHED in 1903, The Story of Cole Younger by Himself is back in print with new footnotes, additional photographs, and an introduction by JamesYounger Gang specialist Marley Brant (St. Paul: Minnesota Historical Society Press, 2000, 127 p., paper, $\$ 12.95$ ) Written after the "old guerrilla" was paroled from Stillwater prison and 25 years after the failed raid on the Northfield bank, the book begins with Younger's childhood days and chronicles his exploits as Civil War soldier, outlaw, convict, and "gentleman." Brant's introduction provides an informed counterpoint to the reformed outlaw's tale, pointing out that Cole "uses the power of the printed word to deny his wrongdoings and elevate himself into a misunderstood, if not honorable, war hero and protector of truth, justice, women, children, and the American way."

SOCIAL, political, and economic change throughout the twentieth century is the important backdrop to historian Oscar J. Martínez's survey, Mexican-Origin People in the United States: A Topical History (Tucson: University of Arizona 